Suat KAYA ${ }^{1}$

Original scientific paper

Assis. Prof. Dr. Vocational School of Civil Aviation

UDC: 371.39

Agri Ibrahim Cecen University, Agri, Turkey

DOI: $10.5937 /$ IstrPed2102586K

\title{
PREDICTORS OF ONLINE LEARNING SATISFACTION OF PRE-SERVICE TEACHERS IN TURKEY2*
}

\begin{abstract}
This research was conducted in an attempt to examine online learning satisfaction (OLS) level of the pre-service teachers and the influence of antecedents including computer anxiety (CA), internet anxiety (IA), online course anxiety (OCA), internet self-efficacy (ISE) and transactions including learner-instructor interaction ( $\mathrm{LII}$ ), learner-content interaction $(\mathrm{LCl})$ and learnerlearner interaction (LLI) on one outcome of online learning process, OLS. We employed an exploratory survey, which can be used to investigate the relationship between certain variables. The sample included 710 pre-service teachers from different departments studying at two public universities located in the eastern part of Turkey. Data were collected through "Technological Anxiety and Satisfaction Scale", "Internet Self-efficacy Sub-scale" and "The Online Self-regulation Questionnaire (OSRQ) in Three Types of Interaction". Descriptive statistics and multiple regression analysis (MLR) were used to analyze the data. The findings indicated low OLS based on the perceptions of this sample of pre-service teachers. Further analysis through MLR revealed a significant negative relationship between OCA and OLS, while the other predictors were insignificant. As the significant predictor explained $14 \%$ of the variance in the outcome variable, more comprehensive research was suggested to find out the unexplained predictors of the outcome. The administrators are suggested to provide the instructors with professional guidance with the help of the experts who can provide successful online course implementations.
\end{abstract}

Keywords: Online learning satisfaction, internet anxiety, computer anxiety, online course anxiety, interactions.

\section{Introduction}

Technological developments and the advances on the internet have had direct influences on the way education is delivered all around the world. This fact has brought about the notion of online learning, which is provided through "electronic versions of traditional courses" (Hong, Lai, \& Holton, 2003: 116). As put forward by Bernard, Abrami, Borokhovski, Wade, Tamim and Surkes (2009), the distance that separates the learning and teaching activities, and the media used to bridge the gap are the main characteristics of online learning. The delivery of online education has increased steadily across the globe over the past decade (Eom \& Ashill, 2016) and ultimately it became the only way of education across the globe due to the COVID-19 pandemic encountered all around the world (Kaya, 2021).

\footnotetext{
1ssukaya@agri.edu.tr,kayasuat2002@gmail.com

2 Part of this paper was presented at the Eighth International Congress on Curriculum and Instruction held on 25-27 March 2021 in Turkey
} 
Literature highlights many benefits of online learning including its lower cost (Casey, 2008; Green, 2010), time-saving measures (Green, 2010); flexibility (Bolliger, 2003; Harsasi \& Sutawijaya, 2018; Hong et al., 2003; Kauffman, 2015; Rekkedal \& Qvist-Eriksen, 2004; Sahin \& Shelley, 2008); usefulness (Sahin \& Shelley, 2008) and potential to reach more students (Green, 2010; Harsasi \& Sutawijaya, 2018). What is even more important is the fact that online learning does not differ significantly from face-to-face education regarding learning gains/outcomes according to the previous studies conducted by Biner, Bink, Huffman and Dean (1997a), Johnson, Aragon, Shaik and Palma-Rivas (2000), Brown and Liedholm (2002) and Allen, Bourhis, Burrell and Mabry (2002). Lou, Bernard and Abrami (2006), who analyzed 103 studies in a metaanalysis, arrived at 218 independent findings and reported that undergraduate students irrespective of whether they received instruction in distant education courses or traditional classrooms achieved similarly on average They concluded that there is little reason to expect distance learning undergraduate students to learn differently from other students when instruction is delivered by the same instructor using the same materials and activities synchronously. Further, U.S. Department of Education (2009) reviewed 51 studies in a metaanalysis which indicated that the students in online learning conditions performed better than those receiving face-to-face instruction. A similar conclusion was reported by Allen, Mabry, Mattrey, Bourhis, Titsworth and Burrell (2004) in their meta-analysis, which showed that the students learning online performed slightly better than did traditionally taught students and they concluded that "distance education technologies do not necessarily create a less effective learning environment and, in some instances, may enhance effectiveness" (p. 415). Hence, it is possible to state that an online course has the potential to be as effective as a face to face course if the necessary conditions and/or predictors are managed effectively.

Literature suggests many predictors of success in online learning (Alshare, Freeze, Lane, \& Wen, 2011; Eom, Wen, \& Ashill, 2006; Mashaw, 2012; Sun, Tsai, Finger, Chen, \& Yeh, 2008; Xu, Huang, Wang, \& Heales, 2014), so these factors need to be managed effectively for a successful online learning. OLS, used to measure whether students are satisfied with their online learning experience (Li, Marsh, Rienties, \& Whitelock, 2016), is determinant of the success of any online program (Dziuban, Moskal, Thompson, Kramer, DeCantis, \& Hermsdorfer, 2015; Rios, Elliott, \& Mandernach, 2018), and it is crucial to academic achievement (Biner, Welsh, Barone, Summers, \& Dean, 1997b). Further, it is highlighted as one of the leading indicators of the quality of the online learning procedures and experiences (Bolliger \& Halupa 2012; Delon \& Mclean, 1992; Harsasi \& Sutawijaya, 2018; Moore \& Kearsley, 1996; Moore, 2005; Parahoo, Santally, Rajabalee \& Harvey, 2016; Yukselturk \& Yildirim, 2008), as it ultimately leads to engagement, learning and thus success (Wickersham \& McGee, 2008). The perspectives of the online learning students yield invaluable data with respect to the strengths and weaknesses of the online learning programs (Noel-Levitz, 2011), which can also be used to evaluate how effective online learning process has been (Arbaugh \& Benbunan- Fich, 2007; So \& Brush, 2008). Keller, Biner et al. (1997b), Allen and Seaman (2008) and Koseke and Koseke believe that "high satisfaction leads to lower attrition rates, higher persistence in learning, and higher motivation in pursuing additional online courses" (Kuo, Walker, Belland, \& Schroder, 2013: 17-18). In the same vein, compared to their counterparts with low satisfaction, students with high satisfaction are expected to be more persistent and more successful in online learning process (Kuo, 2010).

As stated by Parahoo et al. (2016), there is no consensus on a generic framework for predictors of OLS. According to the literature review presented below, it is possible to state that some variables have been repeatedly reported to be significant factors influencing OLS, while some of the variables are insignificant. In addition, some factors reported to be significant in a study have been contradicted in another one. More importantly, most of the related research has been conducted in Western countries, so the results may not be generalized to the developing 
countries, like Turkey. In other words, there is need to undertake research in different contexts to compare results. The purpose of this research, in this sense, was to investigate OLS level of Turkish pre-service teachers and find out the predictors influencing it.

\section{Literature Review}

OLS, which is defined by Astin as "the learner's perception of the value of educational experiences in an educational setting" (Bolliger \& Halupa, 2012: 82), is an important factor influencing the success of online learning process, as satisfied learners are more likely to be successful (Chang \& Smith, 2008). Therefore, many studies have been conducted on this construct and the related literature presents various factors influencing OLS in either positive or negative direction. These factors include responsiveness of the faculty (Herbert, 2006); selfefficacy (Artino, 2007; Gunawardena, Linder-VanBerschot, LaPointe, \& Rao, 2010; Liaw, 2008; Lin, Lin, \& Laffey, 2008; Shen, Cho, Tsai, \& Marra, 2013; Womble, 2008); computer-related problems (Frankola, 2001); anxiety (Bolliger \& Halupa, 2012); technology anxiety (Sun et al., 2008); CA (Saadé \& Kira, 2007; Sun et al. 2008); interaction with instructors (Alqurashi, 2019; Eom, Wen \& Ashill, 2006; Herbert, 2006; Shee \& Wang, 2003; Sher, 2009); LCI (Alqurashi, 2019); LLI (Sher, 2009); instructor behavior (Bolliger \& Martindale, 2004; Dennen, Darabi, \& Smith, 2007); technology and internet quality (Piccoli, Ahmad, \& Ives, 2001; Webster \& Hackley, 1997); system quality (Ozkan \& Koseler, 2009) and the quality of the content (Ozkan \& Koseler, 2009; Sun et al., 2008). Some research findings have been presented in the following paragraphs.

Interaction in its various forms between instructors, students and content has been highlighted as one of the important factors contributing to OLS (Alqurashi, 2019; Chen \& Chen, 2007; Eastman, Aviles, \& Hanna, 2017; Ekwunife-Orakwue \& Teng, 2014; Eom et al., 2006; Kuo, Walker, Schroder, \& Belland, 2014; Parahoo et al., 2016; Paul, Swart, Zhang, \& MacLeod, 2015; Sebastianelli, Swift, \& Tamimi, 2015; Shea, Joaquin, \& Wang, 2016; Swart, MacLeod, Paul, Zhang, \& Gagulic, 2014), perceived learning (Alqurashi, 2019), learners' achievement (Agudo-Peregrina, Iglesias-Pradas, Conde-Gonzalez, \& Hernandez-Garcia, 2014; Ekwunife-Orakwue \& Teng, 2014; Shea, Joaquin, \& Wang, 2016) and learner engagement (Bolliger \& Halupa, 2018), although some disagreements persist. To illustrate, course design, instructor and dialogue were reported to be the strongest predictors of OLS and learning outcomes in the study of Eom and Ashill (2016). Some studies have focused on different types of interaction and differentiated among them. Alqurashi (2019), Kuo et al. (2013) and Kuo et al. (2014) reported LCI and LII as significant predictors of OLS, while LLI was found to be insignificant. Quite similarly, Gray and DiLoreto (2016) reported a small relationship between LLI and OLS. Further, Thurmond (2003), Bolliger and Martindale (2004) and lastly Battalio (2007) reported LII as the best predictor of OLS. Sher (2009) reported LII and LLI as significant predictors of OLS. In the same vein, the findings of the study conducted by Moore (2014) who examined the influence of interaction and some other variables on OLS revealed that LLI and self-discipline were the most influential predictors of OLS and success. However, among three interaction types, Bahaa (2017) reported only LCI as significant predictor of OLS. Lastly, Endres, Chowdhury, Frye and Hurtubis (2009) and Parahoo et al. (2016) reported LII as a significant predictor of OLS and Jung, Choi, Lim and Leem (2002) reported LLI to be more influential than LII.

Further, Cho and Jonassen (2009) introduced interaction regulation concept and they described it as online learners' ability to regulate interaction among the learner, the instructor and the content. In a comparatively recent study, Cho and Cho (2017) found a positive relationship between those interaction types and OLS. Cho, Demei and Laffey (2010) found a positive relationship between interaction regulation and such learner outcomes as social presence, participation in a learning community and perceived learning as well. Interaction 
regulation was reported by Cho and Shen (2013) to influence the time spent in online courses. Kara, Kukul and Cakir (2020) found a positive relationship between self-regulation for interaction and outcomes like perceived learning and OLS.

As online learning is provided through technological devices and the internet, the literature has focused on their influence on OLS as well. Sun et al. (2008) found that internet quality and technology quality were insignificant predictors of OLS in contrast to Piccoli, Ahmad and Ives (2001) and Webster and Hackley (1997). Related to technology, in a sense, Jan (2015) and Wu, Tennyson and Hsia (2010) reported computer self-efficacy, which is a sub-dimension of online learning readiness, as an insignificant predictor of OLS, while Lim (2001) and Womble (2008) reported it as a significant factor. In the same vein, ISE was reported to be a factor influencing success in online learning (Liang \& Tsai, 2008; Tsai, Chuang, Liang, \& Tsai, 2011) and some studies have focused on the relationship between this construct and OLS although the findings are not conclusive. In the studies of Kuo, Walker and Schroder (2010), Kuo et al. (2013), Chu and Chu (2010) and Chu and Tsai (2009), ISE was found to be predictive of OLS, while the studies of Rodriguez Robles (2006) and Puzziferro (2006) reported the opposite.

In direct relation to technology, internet and computers, anxiety about the three has been reported to be an important factor influencing OLS as well. Bolliger and Halupa (2012) examined the relationship between doctoral students' OLS and their technological anxiety and found a significant negative relationship between their OLS and anxiety levels as did Sun et al. (2008). Further, Conrad and Munro (2008) and Rosen, Sears and Weil (1987) found a positive relationship between anxiety and attitude towards technology. In the same vein, positive attitude towards internet technology was reported by Piccoli et al. (2001) to result in higher OLS.

In addition to the constructs and concepts presented above, some other factors have been reported to be influential in OLS levels in previous research. Herbert (2006) found responsiveness of the instructors as the most influential variable in OLS. Especially, timely response was reported by Arbaugh (2002) and Thurmond, Wambach and Connors (2002) to be a significantly positive factor influencing OLS, while it was not significant in the study of Sun et al. (2008). On the other hand, Liaw (2008) drew attention to self-efficacy and Wang (2003) highlighted learner interface as the most important dimension of OLS. In the studies conducted by Artino (2007), Gunawardena et al. (2010), Womble (2008) and Shen et al. (2013), online learning self-efficacy was reported as a significant predictor of OLS. In a recent study, Sharma, Deo, Timalsina, Joshi, Shrestha and Neupane (2020) investigated undergraduate and postgraduate students' OLS level and its predictors. The results indicated that more than half of the students were satisfied with online learning, and the significant predictors were found to be gender on behalf of females, Wi-Fi and learner dimension. What is to add, education level and the area of study have been reported to be among factors influencing OLS. Beqiri, Chase and Bishka (2010) found that graduate, married and male students were more satisfied, while Rodriguez Robles (2006) did not find a significant influence of education level.

\section{Study Rationale and Aim}

Based on the corresponding theory and literature presented above, it is possible to state that these studies have attempted to basically evaluate the online learning curricula. They have mainly focused on the factors that influence the end products of online courses, however, the available literature fails to address this issue. Now that online learning is implemented throughout the world due to the pandemic, it is reasonable to call attention to the evaluation 
of online curricula. Figure 1 presents a theoretical framework suggested by the author to evaluate the overall online learning process based on the corresponding theory and literature. The factors can be called as the antecedents, the transactions and the outcomes as shown in Figure 1. The antecedents are defined by Stake (1967), Gredler (1996), Fitzpatrick et al. (2004), and Ornstein and Hunkins (2017) as "any conditions that exist prior to teaching and learning that may influence outcomes" (Kaya \& Ok, 2020) before the curriculum is run (Wood, 2001). The transactions refer to the classroom activities (Stake, 1967) which include the encounters among stakeholders of learning process (Gredler, 1996) and the students' interactions with certain curriculum materials (Ornstein \& Hunkins, 2017). The outcomes, on the other hand, refer to the end products of a curriculum (Ornstein \& Hunkins, 2017). According to the original evaluation model by Stake (1967), there is relationship among these variables. Simply put, the antecedents and the transactions are supposed to have influence on the outcomes of a curriculum.

Figure 1. A Theoretical Evaluation Framework for Online Learning Curricula

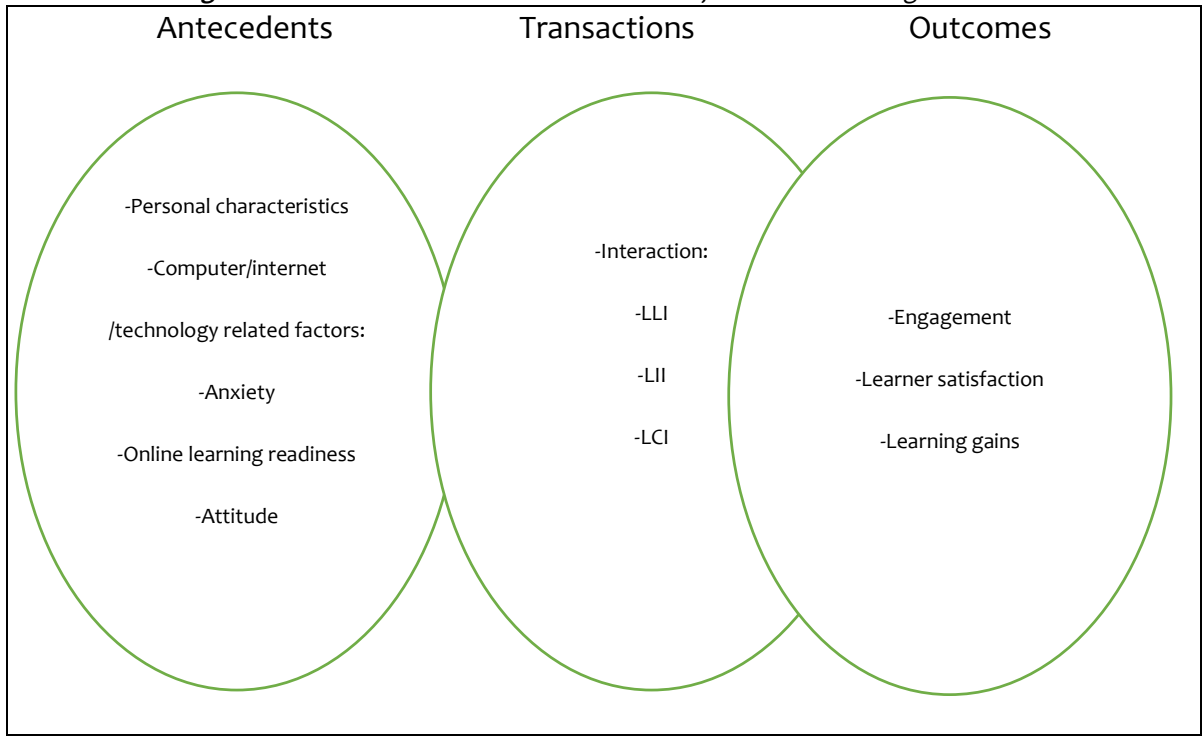

This evaluation model was originally developed and suggested to be used for evaluation traditional curricula (Arnold, 1990; Fitzpatrick, Sanders, \& Worthen, 2004; Gredler, 1996; Ornstein \& Hunkins, 2017; Stake, 1967; Todd, 1992; Wood, 2001). In this research, it was adapted to be used for evaluation of online curricula by changing the variables that can influence the overall online learning process. As can be expected, the variables of online curricula, some of which have been presented in Figure 1, are different from the ones used for the curricula implemented through face to face instruction. Note that this framework is open to improvement and addition of further variables, so there is need to conduct research to find out the potential relationships between and/or among those and different variables in the online learning process. This research is limited to the examination of the relationship between some of these antecedents, transactions and outcomes.

The antecedents specific to online learning courses selected for this research included some learner characteristics such as anxiety and self-efficacy. It can be assumed that they were present before the implementation of online curricula and have further been shaped after the outbreak of the Covid-19 pandemic. The transactions included LLI, LII and LCI. Lastly, the 
outcome included was OLS. The following research question was formulated to find answers for the purpose of this research:

- What is the influence of antecedents (IA, OCA, CA, ISE) and transactions (LLI, LCI, LII) on one outcome of online learning process (pre-service teachers' OLS)?

\section{METHOD}

\section{Research Design}

"Many educational research methods are descriptive; that is, they set out to describe and to interpret what is" (Cohen, Manion, \& Morrison, 2007: 205) and they examine "individuals, groups, institutions, methods and materials in order to describe, compare, contrast, classify, analyse and interpret the entities and the events that constitute their various fields of inquiry" (Cohen et al., 2007: 205). This study employed a survey method which is used to "gather data at a particular point in time with the intention of describing the nature of existing conditions, or identifying standards against which existing conditions can be compared, or determining the relationships that exist between specific events" (Cohen et al., 2007: 205.) "Surveys may vary in their levels of complexity from those that provide simple frequency counts to those that present relational analysis" (Cohen et al., 2007: 205) and they can be "exploratory, in which [... ] relationships and patterns are explored" (Cohen et al., 2007: 207). To this connection, this study examining relationship between certain variables is an exploratory survey.

\section{Sample}

The sample of this research included pre-service teachers learning online at two public universities located in the eastern part of Turkey. The sample included 710 pre-service teachers some characteristics of whom have been shown in Table 1.

Table 1. Demographic Characteristics of the Sample

\begin{tabular}{lllll}
\hline & Categories & $f$ & $\%$ & $M$ \\
\hline Gender & Female & 501 & 70.6 \\
& Male & 209 & 29.4 & 21.2 \\
\hline Une & University A & & & 48.7 \\
& University B & 346 & 41.3 \\
\hline Department & Science & 364 & 51.3 \\
& Turkish & 66 & 9.3 \\
& Maths & 99 & 13.9 \\
& Foreign Language Education & 101 & 14.2 \\
& Early Childhood Education & 81 & 11.4 \\
& Social Sciences & 107 & 15.1 \\
& Elementary School Teaching & 95 & 13.4 \\
& Music & 87 & 12.3 \\
& Art & 48 & 6.8 \\
& First grade & 26 & 3.7 \\
\hline Grade level & Second grade & 332 & 46.8 \\
& Third grade & 203 & 28.6 \\
& & 175 & 24.6 \\
\hline
\end{tabular}

As seen in Table 1, there were more females (70.6\%) than males (29.4\%); the average age was 
21.2; $48.7 \%$ of them from University A, while $51.3 \%$ were from University B; there were more first graders $(46.8 \%)$ than the second $(28.6 \%)$ and third graders (24.6\%). Lastly, there were participants from various departments. Early Childhood Department had the highest proportion (15.1\%), while Art Department had the lowest (3.7\%).

\section{Data Collection Instruments}

As mentioned above, a framework was designed to guide this research. The variables related to the dimensions of antecedents, transactions and outcomes were used to answer the research question. There were two parts in the data collection instrument. The first part had items about some characteristics of the students, while the second part included items about technological anxiety, ISE, interactions and OLS. Permission was taken from the authors of the scales utilized in this research. Detailed information about the reliability and validity of these instruments has been presented below.

The Online Self-regulation Questionnaire (OSRQ) in Three Types of Interaction

This scale was developed by Cho and Cho (2017) and it was adapted to Turkish by Cakir, Kara and Kukul (2019). It included 30 items measured on a seven-point Likert scale ranging from 1 (strongly disagree) to 7 (strongly agree). Cronbach alpha coefficient of the total scale was found to be 0.98 by Cakir et al. (2019). The internal reliability coefficient for the sub-constructs of this scale, which were Self-Regulation in interaction between student and instructor (LII), SR in interaction between student and student (LLI), and SR in interaction between student and content ( $\mathrm{LCl}$ ), were found to be .96, .96 and .95, respectively. The internal reliability coefficient for this scale obtained from the pilot test conducted for this research showed that it had excellent reliability $(a=.90)$, while the values of sub-constructs were also excellent: $\operatorname{LLI}(a=.92)$, LII $(a=.90), \mathrm{LCl}(a=.93)$.

The Internet Self-efficacy Scale

The instrument was originally developed by Joo, Bong and Choi (2000), it was further adapted by Sun et al. (2008) and adapted to Turkish by Ustunel (2016). The original instrument of Ustunel (2016) had 25 items with the sub-constructs of learner attitude towards computers ( 3 items), learner ISE ( 9 items), perceived ease of use (4 items), perceived usefulness (4 items), and perceived E-learning satisfaction ( 5 items). In the current research, only the 9-item measuring learner ISE was used. The original instrument's internal reliability coefficient was found to be 0.93 , quite similarly it was .91 in the current research.

Technological Anxiety and Online Learning Satisfaction Scale

The technological anxiety scale was developed by Bolliger and Halupa (2012). The instrument was composed of three subscales including 18 five-point Likert scale items ranging from 1 (strongly disagree) to 5 (strongly agree). The internal reliability coefficient for this scale was found to be .93, while the internal correlation coefficient values for CA subscale, IA subscale and OCA subscale were $.90, .89$ and .86 , respectively. Literature lacked a valid scale that could be used to measure OLS about all online courses as the previous instruments were mainly developed for a specific course. Therefore, in order to measure learners' satisfaction with the overall online learning experience, four items adapted from Arbaugh (2000), Sun et al. (2008) and Harsasi and Sutawijaya (2018) were added to this instrument.

As part of this research, the instrument was translated into Turkish first. The two most popular judgmental designs are forward translations and backward translations as suggested by Hambleton and Kanje (1993). In this research, the judgmental back-translation design was utilized. In this sense, the items were translated into Turkish by two English linguists, three 
experts from educational science and one expert from computer technologies. Afterwards, these translations were compared and then the best translation for each item was selected. Lastly, another group of translators were required to take the translated Turkish version back into English in order to judge the equivalence. The results showed that the original instrument (source language) and the back-translated version were quite similar, therefore the equivalence of the source and target versions was judged as satisfactory.

Before conducting this translated instrument, two experts from educational sciences checked the items in order to measure the content validity of the instrument. Upon approval from these experts, five students were required to read the items in order to judge whether the items were understood as expected, which refers to face validity. The results showed that the instrument was valid. After the validity studies, construct validity of the instrument was tested through exploratory factor analysis (EFA) as the original instrument lacked information about construct validity. It was employed to 226 pre-service teachers. Some assumptions were checked first to evaluate violations before conducting EFA. Correlation matrix, Kaiser's measure of sampling adequacy (KMO), multivariate normality and Bartlett's Test of Sphericity were examined. With $.826 \mathrm{KMO}$ index value for data set indicated relationship between items. .60 and higher KMO values were advised by Tabachnick and Fidell (2013) as "value close to 1 indicates that patterns of correlations are relatively compact and so factor analysis should yield distinct and reliable factors" (Field, 2013, p. 965). Bartlett's Test of Sphericity was significant with $\chi 2=1662.93, p<$ .05 , indicating that "the correlation matrix has significant correlations among at least some of the variables" (Hair, Black, Babin \& Anderson 2014, p. 102). Mardia's test for multivariate normality produced $p$-value of .69 ( $p>.05)$ and ensured that multivariate normality was not violated, so Maximum Likelihood was used as extraction method (Costello \& Osborne, 2005). Results of factor analysis indicated that there were four factors which explained $73.82 \%$ variation. This variance was judged satisfactory for EFA as "in the social sciences, where information is often less precise, it is not uncommon to consider a solution that accounts for 60 percent of the total variance (and in some instances even less) as satisfactory" (Hair et al., 2014: 107).

Factor loadings of the items and reliability of the scale is presented in Appendix A. According to Hair et al. (2014), factor loadings above. 50 are considered significant, and this is .32 for Tabachnick and Fidell (2013). For Costello and Osborne (2005), below .40 means the item is not related to other items and a factor with fewer than 3 items is weak. According to MacCallum et al. (1999), factors having high loadings and at least three-four items are strong. Judging by the factor loadings of the items and the factors, four-factor model was interpreted as sufficiently representative of the scale as seen in Appendix A. The internal reliability values for this scale obtained from the pilot test showed that it had excellent reliability $(a=.90)$. As suggested by George and Mallery (2003), "anything above 0.90 is excellent, $0.8-0.89$ is good, $0.70-0.80$ is acceptable, $0.60-0.70$ is questionable". Quite similarly, the internal reliability values for the sub-dimensions called CA, IA, OCA and OLS were found to be $.85, .87, .82$, and .89 , respectively. To wrap up, there is enough proof to indicate that Technological Anxiety and Online Learning Satisfaction Scale is a reliable and valid instrument to measure pre-service teachers' technological anxiety and OLS.

\section{Data Collection Process}

Data collection phase started upon approval taken from Ethical permission was taken from "Scientific Research Ethics Committee of Agri Ibrahim Cecen University" with decision numbered 175 in 29.12.2020. An online form was used to gather data. 


\section{Data Analysis}

The quantitative data collected from the participants were analyzed through descriptive and inferential statistics. The dependent variable was OLS, while the independent variables included CA, IA, OCA, ISE, LLI, LII and LCI. All variables could be measured on an interval scale. To put it more, concretely, there was one outcome variable which was predicted by several predictor variables, so multiple regression was used to analyse the influence of these predictors on the outcome variable (Field, 2013). This research had eight variables and the sample size was 710 , which is sufficient to run the analysis in terms of sample size adequacy, as there should be at least 10 observations per variable (Field, 2013; Hair et al., 1998; Tabachnick \& Fidell, 2013). Before conducting MLR, its assumptions were checked. The assumptions included (1) Multicollinearity was checked through VIF values, tolerance values and correlation matrix; (2) Normality of residuals was checked through histogram and P-P plot; (3) Homoscedasticity of residuals was checked through scatter plot; (4) Independence of errors was checked through Durbin-Watson test; and (5) Influential observations was checked through Leverage values, Cook's Distance values, Mahalanobis values and DFBeta. According to Tabachnick and Fidell (2013), VIF values which are below 4 indicate no violation of multicollinearity. The results of this research indicated that VIF values ranged from 1.23 and 1.42. Tolerance values were above .72, which showed no violation of multicollinearity according to Tabachnick and Fidell (2013) who suggest that these values should not be below .10 and .20. In addition, correlation matrix was checked to see if there was correlation between predictors that was above .90 as high correlation between predictor variables above .90 is not desirable (Field, 2013). That is because predictors above .90 contribute to the outcome variable together so one cannot differentiate their individual contribution to outcome variable. As seen in Table 3 below, there were no values above .90 in correlation matrix. Normality of residuals were checked with histogram and a normal curve was observed in the histogram, besides P-P plots were examined and there was a linear line which indicated normally distributed residuals. Homoscedasticity of residuals was checked with scatter plot and no apparent pattern was observed. Independence of errors was checked with Durbin-Watson test and it was 1.81 which causes no violation according to Field (2013) for whom this value should be between 1 and 3. As stated by Fox (1991), "extreme cases have too much impact on the regression solution and also affect the precision of estimation of the regression weights" (Tabachnick \& Fidell, 2013: 124). Therefore, the assumption of influential observation was checked through values of Leverage, Cook's Distance, Mahalanobis Distance and DFBeta to check outliers. According to Stevens (2009), values of Leverage should be below $3(K+1) / N$ and for this research it created a value of $3.9 / 710=.038$. When the data were examined, Leverage values ranged from .003 and .023 , so there was no outlier above the Leverage value of .038. According to Field (2013), the values of Cook's Distance should be below 1 , when the data of this research were examined, all values were found to be below 1 . For Mahalanobis Distance, a value was set according to Chi square table suggested by Tabachnick and Fidell (2013). For 8 variables and considering .001 as an alpha level, 26.12 was set for Mahalanobis Distance. Absence of no values bigger than this set value for this research indicated that there were not any outliers. For DFBeta, as indicated by Field (2013), values above 1 indicate an outlier, but when data set was checked, it was found out that there was no value above 1 . This indicated that there was no outlier. In short, influential observations were not violated. In this sense, it is possible state that there was no violation of these assumptions, so MLR analysis was run. 


\section{FINDINGS}

This research aimed to investigate the influence of antecedents (CA, IA, OCA, ISE) and transactions ( $\mathrm{LLI}, \mathrm{LII}, \mathrm{LCl}$ ) on one outcome of online learning process, OLS. Some descriptive findings have been presented in Table 2 . Note that the minimum values refer to the number of items in each sub/scale.

Starting with OLS, it could have a value between 4 and 20 , the findings showed that it was rather low with a mean of $10.15(S D=4.70)$. Among the anxiety types, $C A(M=16.38, S D=5.84)$ was higher than OCA $(M=16.19, S D=5.49)$ and $I A(M=15.48, S D=4.42)$. Judging by the minimum and maximum values that could be between 6 and 30, it is possible to suggest that the anxiety levels of this sample were not high. Among the interaction types, $\mathrm{LCl}(M=59.05, S D=13.28)$ was higher than LII $(M=46.27, S D=12.72)$ and $\operatorname{LII}(M=45.17, S D=11.33)$. Judging by the minimum and maximum values that could be between 11 and 77, 9 and 63, and 10 and 70 for LCl, LII and LLI, respectively, it is possible to state that there was satisfactory interaction. Lastly, ISE of this sample was quite high $(M=22.33, S D=4.16)$ judging by the minimum and maximum values that could be between 9 and 27 .

Table 2. Descriptive Statistics of the Variables

\begin{tabular}{lllll}
\hline & Min. & Max. & $\boldsymbol{M}$ & SD \\
\hline 1. OLS & 4 & 20 & 10.15 & 4.70 \\
2. CA & 6 & 30 & 16.38 & 5.84 \\
3. IA & 6 & 30 & 15.48 & 4.42 \\
4. OCA & 6 & 30 & 16.19 & 5.49 \\
5. LLI & 10 & 70 & 45.17 & 11.33 \\
6. LCI & 11 & 77 & 59.05 & 13.28 \\
7. LII & 9 & 63 & 46.27 & 12.72 \\
8. ISE & 9 & 27 & 22.33 & 4.16 \\
\hline
\end{tabular}

Initial glance at correlation matrix indicated that there was correlation among variables as can be seen in Table 3. Further, the potentially best predictor seemed to be OCA $(r=-.35)$, while LII seemed to be the least powerful predictor $(r=.16)$.

Table 3. Correlation Matrix of the Variables

\begin{tabular}{lllllllll}
\hline Variables & $\mathbf{1}$ & $\mathbf{2}$ & $\mathbf{3}$ & 4 & 5 & 6 & $\mathbf{7}$ & $\mathbf{8}$ \\
\hline 1. OLS & 1 & & & & & & & \\
2. CA & -.24 & 1 & & & & & & \\
3. IA & -.20 & .61 & 1 & & & & & \\
4. OCA & -.35 & .50 & .47 & 1 & & & & \\
5. LLI & .19 & -.19 & -.20 & -.27 & 1 & & & \\
6. LCI & .18 & -.17 & -.18 & -.23 & .52 & 1 & & \\
7. LII & .16 & -.17 & -.18 & -.27 & .53 & .55 & 1 & \\
8. ISE & .19 & -.32 & -.35 & -.29 & .21 & .30 & .32 & 1 \\
\hline
\end{tabular}

Table 4 presents the results of the model summary table of multiple regression analysis, while Table 5 shows the results of ANOVA. 
Table 4. Model Summary Table of MLR Analysis

\begin{tabular}{|c|c|c|c|c|c|c|c|c|}
\hline \multirow{2}{*}{ Model } & \multirow{2}{*}{$R$} & \multirow{2}{*}{$R^{2}$} & \multirow{2}{*}{$\begin{array}{l}\text { Adjusted } \\
\mathrm{R}^{2}\end{array}$} & \multirow{2}{*}{ SE } & \multicolumn{4}{|c|}{ Change Statistics } \\
\hline & & & & & $\Delta \mathbf{R}^{2}$ & $\Delta \mathbf{F}$ & df1 & $\mathrm{df}_{2}$ \\
\hline 1 & .38 & .14 & .13 & 4.35 & .14 & $14.54^{*}$ & 8 & 692 \\
\hline
\end{tabular}

As can be seen in Table 4 and Table 5 , the model was statistically significant $(F=14.54, p<.05)$. These findings indicated that at least one of the predictors caused change in the outcome variable. In other words, the predictors in the regression model predicted OLS significantly. Further, the $R^{2}$ value was found to be .14 indicating that $14 \%$ of variation in OLS was accounted for the significant predictor/s in the model.

Table 5. ANOVA Table of MLR Analysis

\begin{tabular}{lllll}
\hline \multicolumn{1}{c}{ Model } & SS & Df & F \\
\hline \multirow{4}{*}{1} & Regression & 2203.85 & 8 & $14.54^{*}$ \\
& Residual & 13112.20 & 692 & \\
& Total & 15315.93 & 700 & \\
\hline
\end{tabular}

${ }^{*} p<.05$

Though these findings showed whether the model was significant or not, they failed to show the individual contribution of the variables in the regression model. Table 6 shows that the only significant variable influencing OLS was OCA with a B-value of $-.24(t(692)=-.6 .49, p<.05)$. It indicated a negative relationship. More concretely, as OCA increased, OLS decreased.

Table 6. Summary of the MLR Analysis for the Predictors of OLS

\begin{tabular}{llllllll}
\hline & Variables & B & SE B & B & $t$ & $R^{2}$ & $\boldsymbol{\Delta} \boldsymbol{F}$ \\
\hline Model 1 & 1. OLS & 10.81 & 1.67 & & $2.48^{*}$ & .14 & $14.54^{*}$ \\
& 2. CA & -.06 & .04 & -.08 & -1.61 & & \\
& 3. IA & .03 & .05 & .03 & .63 & & \\
& 4. OCA & -.24 & .04 & -.28 & $-6.49 *$ & & \\
& 5. LLI & .02 & .02 & .06 & 1.30 & & \\
6. LCI & .02 & .02 & .07 & 1.52 & & \\
& 7. LII & -.00 & .02 & -.01 & -.19 & & \\
& 8. ISE & .07 & .05 & .06 & 1.60 & & \\
\hline
\end{tabular}

${ }^{*} p<.05$

\section{DISCUSSION, CONCLUSION AND RECOMMENDATIONS}

This research was undertaken to find out the influence of antecedents (CA, IA, OCA, ISE) and transactions (LII, LLI, LCI) on one outcome of online learning process (OLS). There was one outcome variable which was predicted by several predictor variables, so MLR was used to examine the influence of those predictors on the outcome variable.

The preliminary findings derived from descriptive analysis revealed that the pre-service teachers were not satisfied with the online learning process in contrast to the previous studies (Bolliger \& Halupa 2012; Sharma et al., 2020). This could be attributed to the characteristics of 
the sample and the instructors who have not experienced online teaching before the pandemic. Learner dissatisfaction is probably due to the emergency transition to online education with a limited instructional design appropriate with online learning and instructor incompetency in this regard as well as learner readiness. That is because previous research mainly focused on OLS with a specific course which means that the instructors might have planned the delivery of the online course before. However, all instructors were required to provide online courses without knowing whether they were ready to, which might have caused problems in the process. Considering OLS as one of the leading indicators of the quality of online learning experiences (Bolliger \& Halupa 2012; Delon \& Mclean, 1992; Harsasi \& Sutawijaya, 2018; Moore \& Kearsley, 1996; Moore, 2005; Parahoo et al., 2016; Yukselturk \& Yildirim, 2008), its potential to increase the success of any online program (Dziuban et al. 2015; Rios et al., 2018) and academic achievement (Biner et al., 1997b), this finding indicates that the quality of the online courses offered is questionable. Further, the possibility of the expected academic achievement and/or learning gains seems far away.

Although the pre-service teachers' satisfaction was low, their computer-related anxiety including CA, IA and OCA, which have been reported to be influencing satisfaction in a negative way (Bolliger \& Halupa, 2012; Saade \& Kira, 2007; Sun et al., 2008), were found to be rather low. Quite similarly, their interaction with the instructor, the content and each other, which was expected to influence OLS level (Alqurashi, 2019; Ekwunife-Orakwue \& Teng, 2014; Kuo et al., 2014; Parahoo et al., 2016; Paul et al., 2015; Shea et al., 2016; Swart et al., 2014) was found to be high. Last, their ISE, expected to contribute to the OLS in a positive direction (Chu \& Chu, 2010; Chu \& Tsai, 2009; Kuo, Walker \& Schroder, 2010, Kuo et al., 2013) yielded high results.

Depending on these descriptive results, OLS would be expected to be quite high. However, the result was unexpectedly low. In order to find out the significant factors contributing to this result, MLR was conducted. In contrast to Kuo, Walker and Schroder (2010), Kuo et al. (2013), Chu and Chu (2010) and Chu and Tsai (2009) who reported ISE to be predictive of satisfaction, this research reported it as an insignificant predictor in line with the studies of Rodriguez Robles (2006) and Puzziferro (2006).

In the same vein, unlike the previous research studies which reported LLI (Endres et al., 2009; Eom \& Ashill, 2016; Gray \& DiLoreto, 2016; Moore, 2014; Parahoo et al., 2016; Sher, 2019), LCI (Alqurashi, 2019; Bahaa, 2017; Kuo et al. (2013); Kuo et al., 2014) and LII (Alqurashi, 2019; Battalio, 2007; Bolliger \& Martindale, 2004; Eom \& Ashill, 2016; Kuo et al., 2013; Kuo et al., 2014; Sebastianelli et al., 2015; Sher, 2019; Thurmond, 2003) as significant predictors of OLS, this research found non-significant influence of these predictors. This result could be attributed to the different instruments utilized in these studies.

The only predictor influencing OLS significantly was found to be OCA, which is partly in line with the study of Bolliger and Halupa (2012). On the other hand, CA, which was reported by Sun et al. (2008) as a significant factor, and IA were insignificant in this research. The predictor significant in this research explained only $14 \%$ of variance in the outcome variable. This indicates the existence of more influential unexplained factors, not included in this research, which could be influencing the outcome.

Last, this research revealed quite different findings from the prior studies which could be attributed to the contextual factors and the urgent transition to online learning process. Besides, the previous studies were conducted with students who had a few online courses, however the students included in this studies took all of their courses online. More concretely, the students were exposed to so many online courses during the pandemic, which might have 
influenced their perceptions and thus the results. In this sense, it is possible to state that the results might possibly change after the pandemic when the students are exposed to just a few online courses delivered by the instructors well-prepared for online instruction.

\section{Implications for Practice}

This research provides some implications and insights for policy makers, researchers and instructors to improve OLS, as it was found to be rather low. The literature has provided proof that online learning can be as effective as face to face instruction; however, the negative perceptions might hamper students' willingness to engage in online courses, which in turn might result in failure in terms of academic achievement. The main reason decreasing OLS was found to be OCA, which indicates that the students feel anxious when required to participate in online courses. This can be attributed to the intensive amount of online learning, the quality of the course or some other variables related to the course, the instructor etc., so more enjoyable course designs are suggested to be developed and implemented. In this sense, the administrators are suggested to provide the instructors with professional guidance with the help of the experts who can provide successful online course implementations. Last, the instructors should be encouraged to develop and implement an online course even after the pandemic is over.

\section{Limitations of the Study and Implications for Further Research}

Although this research was planned and undertaken carefully, it is not without limitations. Above all, the pre-service teachers' satisfaction was rather low in this research, only one predictor (OCA) was found to be significant and it could explain $14 \%$ of variance in the OLS. To this connection, there is need for more comprehensive research to find out the unexplained factors causing low level of OLS or factors increasing OLS level. As a suggestion, an in-depth qualitative research conducted with the ones having low satisfaction levels might work well. In the same direction, further research might be planned to find out the factors predicting the other dependent/outcome variables, which are engagement and academic achievement. Third, the findings of this research relied on the self-reported data, therefore they should be evaluated or interpreted with caution. In addition, the sample of this study included various programs of teacher education departments, so further research might focus on program-specific and even course specific examinations in order to find out specific reasons for this dissatisfaction or different predictors influencing OLS. Last, convenience sampling method was used and the participants were only from two universities, so the generalizability of these findings should be interpreted with caution. To this connection, further research might collect data from more universities located in different regions of Turkey for more generalizability.

\section{References:}

Abrami, P. C., Bernard, R. M., Bures, E. M., Borokhovski, E., \& Tamim, R. M. (2011). Interaction in distance education and online learning: Using evidence and theory to improve practice. Journal of Computing in Higher Education, 23(2-3), 82-103. doi:10.1007/s12528011-9043-X

Agudo-Peregrina, A. F., Iglesias-Pradas, S., Conde-Gonzalez, M. A., \& Hernandez-Garcia, A. (2014). Can we predict success from log data in VLEs? Classification of interactions for learning analytics and their relation with performance in VLE-supported $\mathrm{F} 2 \mathrm{~F}$ and online learning. Computers in Human Behavior, 31, 542-550. 
Allen, M., Bourhis, J., Burrell, N., \& Mabry, E. (2002). Comparing student satisfaction with distance education to traditional classrooms in higher education: A metaanalysis. The American Journal of Distance Education, 16(2), 83-97. https://doi.org/10.1207/S15389286AJDE1602_3

Allen, M., Mabry, E., Mattrey, M., Bourhis, J., Titsworth, S., \& Burrell, N. (2004). Evaluating the effectiveness of distance learning: A comparison using meta-analysis. Journal of Communication, 402-420.

Allen, I. E., \& Seaman, J. (2008). Staying the course: Online education in the United States, 2008. USA: Sloan Consortium. Retrieved from

https://www.onlinelearningsurvey.com/reports/staying-the-course.pdf in 04.10.2020.

Alqurashi, E. (2019). Predicting student satisfaction and perceived learning within online learning environments. Distance Education, 40(1), 133-148.

https://doi.org/10.1080/01587919.2018.1553562

Alshare, K. A., Freeze, R. D., Lane, P. L., \& Wen, H. J. (2011). The impacts of system and human factors on online learning systems use and learner satisfaction. Decision Sciences Journal of Innovative Education, 9(3), 437-461. https://doi.org/10.1111/j.15404609.2011.00321.X

Arbaugh, J. B. (2002). Managing the on-line classroom: a study of technological and behavioral characteristics of web-based MBA courses. Journal of High Technology Management Research, 13, 203-223. https://doi.org/10.1016/S1047-8310(02)00049-4

Arbaugh, J. B., \& Benbunan-Fich, R. (2007). The importance of participant interaction in online environments. Decision Support Systems, 43(3), 853-865. doi:10.1016/j. dss.2006.12.013

Arnold, S. (1990). An action research evaluation of a computer enhanced senior secondary mathematics curriculum. Unpublished master's thesis, University of Wollongong, Australia.

Artino, A. R. (2007). Motivational beliefs and perceptions of instructional quality: Predicting satisfaction with online training. Journal of Computer Assisted Learning, 24(3), 260270. https://doi.org/10.1111/j.1365-2729.2007.00258.x

Bahaa G. G. (2017). Learner satisfaction with massive open online courses. American Journal of Distance Education, 31(2), 98-111. Doi: 10.1080/08923647.2017.1300462

Battalio, J. (2007). Interaction online: A reevaluation. Quarterly Review of Distance Education, 8(4),339-352. Retrieved from http://www.anitacrawley.net/Resources/Articles/INTERACTION\%200NLINE.pdf

Beqiri, M. S., Chase, N. M., \& Bishka, A. (2010). Online course delivery: An empirical investigation factors affecting student satisfaction. Journal of Education for Business, 85(2), 95-100. https://doi.org/10.1080/08832320903258527

Bernard, R. M., Abrami, P. C., Borokhovski, E., Wade, C. A., Tamim, R. M., \& Surkes, M. A. (2009). A meta-analysis of three interaction treatments in distance education. Review of Educational Research, 79, 1243-1289. https://doi.org/10.3102/0034654309333844

Biner, P.M., Bink, M. L., Huffman, M. L., \& Dean, R. S. (1997a). The impact of remote-site group size on student satisfaction and relative performance in interactive telecourses. The American Journal of Distance Education, 11(1), 23-33. https://doi.org/10.1080/08923649709526949

Biner, P.M., Welsh, K. D., Barone, N. M., Summers, M., \& Dean, R. S. (1997b). The impact of remote-site group size on student satisfaction and relative performance in interactive telecourses. American Journal of Distance Education, 11(1), 23-33. https://doi.org/10.1080/08923649709526949

Bolliger, D. U. (2003). The design and field test of a Web-based training program for future school administrators in a northwest Florida school district. Journal of Interactive Online Learning, 1(3), 1-12. 
Bolliger, D. U., \& Martindale, T. (2004). Key factors for determining student satisfaction in online courses. International Journal on E-Learning, 3, 61-67.

Bolliger, D. U., \& Halupa, C. (2012). Student perceptions of satisfaction and anxiety in an online doctoral program. Distance Education 33(1), 81-98.

Bolliger, D. U., \& Halupa, C. (2018). Online student perceptions of engagement, transactional distance, and outcomes. Distance Education, 39(3), 299-316. sep?

Brown, B. W., \& Liedholm, C. E. (2002). Can web courses replace the classroom in principles of microeconomics? American Economics Review, 92(2), 444-448. Doi: 10.1257/000282802320191778

Cakir, R., Kara, M., \& Kukul, V. (2019). Adaptation of the online self-regulation questionnaire (OSRQ) in three types of interaction into Turkish: A validity and reliability study. Educational Technology Theory and Practice, 9(2), 332-348.

https://doi.org/10.17943/etku.499407

Casey, D. (2008). A journey to legitimacy: the historical development of distance education through technology. TechTrends, 52(2), 45-51.

Chang, S. H., \& Smith, R. A. (2008). Effectiveness of personal interaction in a learner-centered paradigm distance education class based on student satisfaction. Journal of Research on Technology in Education, 40(4), 407-426.

https://doi.org/10.1080/15391523.2008.10782514

Chen, Y.-J., \& Chen, P.-C. (2007). Effects of online interaction on adult students' satisfaction and learning. The Journal of Human Resource and Adult Learning, 3(2), 78-89. doi:10.1080/14703290252934603

Cho, M. H., \& Cho, Y. (2017). Self-regulation in three types of online interaction: A scale development. Distance Education, 38(1), 70-83.

https://doi.org/10.1080/01587919.2017.1299563

Cho, M. H., Demei, S., \& Laffey, J. (2010). Relationships between self-regulation and social experiences in asynchronous online learning environments. Journal of Interactive Learning Research, 21(3), 297-316.

Cho, M. H., \& Jonassen, D. (2009). Development of the human interaction dimension of the SelfRegulated Learning Questionnaire in asynchronous online learning environments. Educational Psychology, 29(1), 117-138.

Cho, M. H., \& Shen, D. (2013). Self-regulation in online learning. Distance Education, 34(3), 290301.

Chu, R. J., \& Chu, A. Z. (2010). Multi-level analysis of peer support, Internet self-efficacy and elearning outcomes: The contextual effects of collectivism and group potency. Computer \& Education, 55, 145-154. https://doi.org/10.1016/j.compedu.2009.12.011

Chu, R. J., \& Tsai, C. C. (2009). Self-directed learning readiness, Internet self-efficacy and preferences towards constructivist Internet-based learning environments among higher-aged adults. Journal of Computer Assisted Learning, 25, 489-501. https://doi.org/10.1111/j.1365-2729.2009.00324.x

Cohen, L., Manion, L. \& Morrison, K. (2007). Research methods in education (6 $6^{\text {th }}$ Ed). London and New York: Taylor and Francis Group.

Conrad, A. M., \& Munro, D. (2008). Relationships between computer self-efficacy, technology, attitudes and anxiety: Development of the computer technology use scale (CTUS). Journal of Educational Computing Research, 39, 51-73. doi: 10.2190/EC. 39.1.d

Costello, A. B., \& Osborne, J. W. (2005). Best practices in exploratory factor analysis: Four recommendations for getting the most from your analysis. Practical Assessment, Research \& Evaluation, 10(7), 1-9.

Delon, W., \& Mclean, E. (1992). Information systems success: The quest for the dependent variable. Information Systems Research, 3(1), 60-95. SEEF? 
Dennen, V. P., Darabi, A. A., \& Smith, L. J. (2007). Instructor-learner interaction in online courses: The relative perceived importance of particular instructor actions on performance and satisfaction. Distance Education, 28, 65-79. Doi: 10.1080/ 01587910701305319

Dziuban, C., Moskal, P., Thompson, J., Kramer, L., DeCantis, G., \& Hermsdorfer, A. (2015). Student satisfaction with online learning: Is it a psychological contract? Online Learning, 19(2), 122-136. doi:10.24059/olj.v19i2.496

Eastman, J. K., Aviles, M., \& Hanna, M. D. (2017). Determinants of perceived learning and satisfaction in online business courses: An extension to evaluate differences between qualitative and quantitative courses. Marketing Education Review, 27(1), 51-62. DOI: 10.1080/10528008.2016.1259578

Ekwunife-Orakwue, K. C., \& Teng, T. L. (2014). The impact of transactional distance dialogic interactions on student learning outcomes in online and blended environments. Computers \& Education, 78, 414-427.

Endres, M. L., Chowdhury, S., Frye, C., \& Hurtubis, C. A. (2009). The multifaceted nature of online MBA student satisfaction and impacts on behavioral intentions. Journal of Education for Business, 84(5), 304-312. https://doi.org/10.3200/JOEB.84.5.304-312

Eom, S. B., \& Ashill, N. (2016). The determinants of students' perceived learning outcomes and satisfaction in university online education: An update. Decision Sciences Journal of Innovative Education

Eom, S. B., Wen, H. J., \& Ashill, N. (2006). The determinants of students' perceived learning outcome and satisfaction in university online education: An empirical investigation. Decision Sciences Journal of Innovative Education, 4(2), 215-236.

https://doi.org/10.1111/j.1540-4609.2006.00114.x

Field, A. (2013). Discovering statistics using IBM SPSS statistics. (4th ed.). Los Angeles: Sage.

Fitzpatrick, J. L., Sanders, J. R., \& Worthen, B. R. (2004). Introduction to evaluation: evaluation's basic purpose, uses, and conceptual distinctions. Curriculum evaluation alternative approaches and practical guidelines. USA: Pearson Education.

Frankola, K. (2001). Why online learners drop out. Workforce, 80(10), 53-59.

George, D., \& Mallery, P. (2003). SPSS for Windows step by step: A simple guide and reference. 11.0 update. Boston: Allyn \& Bacon.

Gray, J. A., \& DiLoreto, M. (2016). The effects of student engagement, student satisfaction, and perceived learning in online learning environments. International Journal of Educational Leadership Preparation, 11(1), 98-119. Retrieved from https://files.eric.ed.gov/fulltext/EJ1103654.pdf

Gredler, M., E. (1996). Curriculum evaluation. USA: Pearson Education Company.

Green, K. C. (2010). The Campus Computing Survey. Encino, CA: e Campus Computing Project. Retrieved from https://www.campuscomputing.net/content/2010/10/17/the-2010campus-computing-survey in 02.10.2020.

Gunawardena, C. N., Linder-VanBerschot, J. A., LaPointe, D. K., \& Rao, L. (2010). Predictors of learner satisfaction and transfer of learning in a corporate online education programme. American Journal of Distance Education, 24(4), 207-226. https://doi.org/10.1080/08923647.2010.522919

Hair, J.F., Anderson, R.E., Tatham, R.L. \& Black, W.C. (1998). Multivariate data analysis. (5th ed.). Upper Saddle River, NJ: Prentice Hall.

Hair, J. F., Black, W. C., Babin, B. J., \& Anderson, R. E. (2014). Multivariate data analysis. (7th ed.). USA: Pearson.

Hambleton, R.K., \& Kanjee, A. (1993, April). Enhancing the validity of cross-cultural studies: improvements in instrument translation methods. Paper presented at the Annual Meeting of the American Educational Research Association, Atlanta, GA (April 12-16). 
Harsasi, M., \& Sutawijaya, A. (2018). Determinants of student satisfaction in online tutorial: A study of a distance education institution. The Turkish Online Journal of Distance Education, 19, 89-99.

Herbert, M. (2006). Staying the course: A study in online student satisfaction and retention. Online Journal of Distance Learning Administration, 9(4). Retrieved from http://www. westga.edu/ distance/ojdla/

Hong, K. S., Lai, K. W., \& Holton, D. (2003). Students' satisfaction and perceived learning with web-based course. Educational Technology and Society, 6(1), 116-124.

Jan, S. K. (2015). The relationships between academic self-efficacy, computer self-efficacy, prior experience, and satisfaction with online learning. American Journal of Distance Education, 29(1), 30-40. https://doi.org/10.1080/08923647.2015.994366

Johnson, S. D., Aragon, S. R., Shaik, N., \& Palma-Rivas, N. (2000). Comparative analysis of learner satisfaction and learning outcomes in online and face-to-face learning environments. Journal of Interactive Learning Research, 11(1), 29-49.

Joo, Y. J., Bong, M., \& Choi, H. J. (2000). Self-efficacy for self-regulated learning, academic selfefficacy, and internet self-efficacy in web based instruction. Educational Technology Research and Development, 48(2), 5-17.

Jung, I., Choi, S., Lim, C., \& Leem, J. (2002). Effects of different types of interaction on learning achievement, satisfaction and participation in web-based instruction. Innovations in Education \& Teaching International, 39(2), 153-162.

https://doi.org/10.1080/14703290252934603

Kara, M., Kukul, V., \& Cakir, R. (2020). Self-regulation in three types of online interaction: How does it predict online pre-service teachers' perceived learningispep:and satisfaction? The Asia-Pacific Education Researcher, (2020). https://doi.org/10.1007/s40299-020-00509-X

Kauffman, H. (2015). A review of predictive factors of student success in and satisfaction with online learning. Research in Learning Technology, 23.

https://doi.org/10.3402/rlt.v23.26507

Kaya, S. (2021). The factors predicting students' participation in online English courses. Eurasian Journal of Educational Research 91, 301-320, https://doi.org/10.1468g/ejer.2021.91.14

Kaya, S. \& Ok, A. (2020). The Antecedents influencing the implementation and success of the middle school English language curriculum. International Journal of Contemporary Educational Research, 7(1), 201-214. https://doi.org/10.33200/ijcer.660386

Kuo, Y.-C., (2010). Interaction, internet self-efficacy, and self-regulated learning as predictors of student satisfaction in distance education courses. All Graduate Theses and Dissertations. 741. https://digitalcommons.usu.edu/etd/741

Kuo, Y.-C., Walker, A., \& Schroder, K. E. E. (2010). Interaction and other variables as predictors of student satisfaction in online learning environments. Paper presented at the annual meeting of the Society for Information Technology \& Teacher Education (SITE), March 29 2010, San Diego, California.

Kuo, Y.-C., Walker, A., Belland, B. \& Schroder, K. (2013). A predictive study of student satisfaction in online education programs. International Review of Research in Open and Distributed Learning, 14 (1), 16-39. https://doi.org/10.19173/irrodl.v14i1.1338

Kuo, Y.-C., Walker, A. E., Schroder, K. E. E., \& Belland, B. R. (2014). Interaction, internet selfefficacy, and self-regulated learning as predictors of student satisfaction in online education courses. The Internet and Higher Education, 20, 35-50. https://doi.org/10.1016/j.iheduc.2013.10.001

Li, N., Marsh, V., Rienties, B., \& Whitelock, D. (2016). Online learning experiences of new versus continuing learners: A large-scale replication study. Assessment \& Evaluation in Higher Education, 1-16. http://dx.doi.org/10.1080/02602938.2016.1176989 
Liang, J. C., \& Tsai, C. C. (2008). Internet self-efficacy and preferences toward constructivist Internet-based learning environments: A study of pre-school teachers in Taiwan. Educational Technology \& Society, 11(1), 226-237. Retrieved from

https://www.jstor.org/stable/10.2307/jeductechsoci.11.1.226

Liaw, S. (2008). Investigating students' perceived satisfaction, behavioral intention, and effectiveness of e-learning: A case study of the Blackboard system. Computers \& Education, 51, 864-873.

Lim, C. K. (2001). Computer self-efficacy, academic self-concept, and other predictors of satisfaction and future participation of adult distance learners. American Journal of Distance Education, 15(2), 41-51. https://doi.org/10.1080/08923640109527083

Lin, Y., Lin, G., \& Laffey, J. M. (2008). Building a social and motivational framework for understanding satisfaction in online learning. Journal of Educational Computing Research, 38, 1-27. doi: 10.2190/EC.38.1.a

Lou, Y., Bernard, R., \& Abrami, P. C. (2006). Undergraduate distance education: A theory-based meta-analysis of the literature. Educational Technology Research and Development, 54(2), 141-176.

MacCallum, R.C, Widaman, K.F., Zhang, S. \&Hong, S. (1999). Sample size in factor analysis. Psychological Methods, 4, 84-99.

Mashaw, B. (2012). A model for measuring effectiveness of an online course. Decision Sciences Journal of Innovative Education, 10(2), 189-221. https://doi.org/10.1111/j.15404609.2011.00340.x

Moore, M. G., \& Kearsley, G. (1996). Distance education: A systems view. New York, NY: Wadsworth.

Moore, J. C. (2005). The sloan consortium quality framework and the five pillars. Retrieved from http://www.mit.jyu.fi/OPE/kurssit/TIES462/Materiaalit/Sloan.pdf on $13^{\text {th }}$ October 2020.

Moore, J. (2014). Effects of online interaction and instructor presence on students' satisfaction and success with online undergraduate public relations courses. Journalism \& Mass Communication Educator, 69(3), 271-288. doi:10.1177/1077695814536398

Noel-Levitz. (2011). National online learners priorities report. Retrieved from https://www.noellevitz.com/upload/Papers_and_Research/2011/PSOL_report $\%$ 202011.pdf on 04 $4^{\text {th }}$ October 2020

Ornstein, A. C., \& Hunkins, F. P. (2017). Curriculum: Foundations, principles and issues (7th ed.). USA: Pearson Education Limited.

Ozkan, S., \& Koseler, R. (2009). Multi-dimensional students' evaluation of e-learning systems in the higher education context: An empirical investigation. Computers \& Education, 53, $1285-1296$.

Parahoo, S. K., Santally, M. I., Rajabalee, Y., \& Harvey, H. L. (2016). Designing a predictive model of student satisfaction in online learning. Journal of Marketing for Higher Education, 26(1), 1-19. https://doi.org/10.1080/08841241.2015.1083511

Paul, R. C., Swart, W., Zhang, A. M., \& MacLeod, K. R. (2015). Revisiting Zhang's scale of transactional distance: Refinement and validation using structural equation modeling. Distance Education, 36(3), 364-382.

Piccoli, G., Ahmad, R., \& Ives, B. (2001). Web-based virtual learning environments: a research framework and a preliminary assessment of effectiveness in basic IT skill training. MIS Quarterly, 25(4), 401-426.

Puzziferro, M. (2006). Online technologies self-efficacy, self-regulated learning, and experiential variables as predictors of final grade and satisfaction in college-level online courses. (Doctoral dissertation). Available from Dissertations and Theses database. (UMI No. 3199984)). 
Rekkedal, T., \& Qvist-Eriksen, S. (2004). Student support services in e-learning: An evalua- tion study of students' needs and satisfaction. European Journal of Open, Distance and ELearning. Retrieved from http://www.eurodl.org/ on 14 October 2020.

Rodriguez Robles, F. M. (2006). Learner characteristic, interaction and support service variables as predictors of satisfaction in web-based distance education. Dissertation Abstracts International, 67(7) (UMI No. 3224964).

Rios, T., Elliott, M., \& Mandernach, B. J. (2018). Efficient instructional strategies for maximizing online student satisfaction. Journal of Educators Online, 15(3), 158-166.

Rosen, L. D., Sears, D. C., \& Weil, M. M. (1987). Computerphobia. Behavior Research Methods, Instruments, \& Computers, 19(2),167-179.

Saadé, R. G., \& Kira, D. (2007). Mediating the impact of technology usage on perceived ease of use by anxiety. Computers \& Education, 49, 1189-1204. doi: 10.1016/j.compedu.2006.01.009

Sahin, I., \& Shelley, M. (2008). Considering students' perceptions: The distance education student satisfaction model. Educational Technology and Society, 11(3), 216-223.

Sebastianelli, R., Swift, C, \& Tamimi, N. (2015). Factors affecting perceived learning, satisfaction, and quality in the online mba: a structural equation modeling approach. Journal of Education for Business, 90,296-305. https://doi.org/10.1080/08832323.2015.1038979

Sharma K., Deo G., Timalsina S., Joshi A., Shrestha N., \& Neupane, H. C.(2020). Online Learning in the face of COVID-19 Pandemic: Assessment of students' Satisfaction at Chitwan Medical College, Nepal. Kathmandu University Medical Journal, COVID-19 Special Issue 70(2), 40-47.

Shea, J., Joaquin, M. E., \& Wang, J. Q. (2016). Pedagogical design factors that enhance learning in hybrid courses: A contribution to design-based instructional theory. Journal of Public Affairs Education, 22(3), 381-397.

Shee, D. Y., \& Wang, Y. (2008). Multi-criteria evaluation of the web-based e-learning sys- tem: A methodology based on learner satisfaction and its applications. Computers \& Education, 50, 894-905. doi: 10.1016/j.compedu.2006.09.005

Shen, D., Cho, M.-H., Tsai, C.-L., \& Marra, R. (2013). Unpacking online learning experiences: Online learning self-efficacy and learning satisfaction. The Internet and Higher Education, 19, 10-17. https://doi.org/10.1016/j.iheduc.2013.04.001

Sher, A. (2009). Assessing the relationship of student-instructor and student-student interaction to student learning and satisfaction in Web-based Online Learning Environment. Journal of Interactive Online Learning 8(2), 102-120.

So, H.-J., \& Brush, T. A. (2008). Student perceptions of collaborative learning, social presence and satisfaction in a blended learning environment: relationships and critical factors. Computers \& Education, 51(1), 318-336. Doi:10.1016/j.compedu.2007.05.009

Stake, R. E. (1967). The countenance of educational evaluation. Teachers College Record, 68, 523540.

Sun, P.-C., Tsai, R., Finger, G., Chen, Y.-Y., \& Yeh, D. (2008). What drives a successful E-learning? An empirical investigation of the critical factors influencing learner satisfaction. Computers \& Education, 50, 1183-1202. doi:10.1016/j.compedu.2006.11.007

Swart, W., MacLeod, K., Paul, R., Zhang, A., \& Gagulic, M. (2014). Relative proximity theory: Measuring the gap between actual and ideal online course delivery. American Journal of Distance Education, 28(4), 222-240.

Tabachnick, B. G., \& Fidell, L. S. (2013). Using multivariate statistics. (6th ed.). Pearson.

Thurmond, V. A., Wambach, K., \& Connors, H. R. (2002). Evaluation of student satisfaction: determining the impact of a web-based environment by controlling for student characteristics. The American Journal of Distance Education, 16(3), 169-189.

Thurmond, V. A. (2003). Examination of interaction variables as predictors of students' satisfaction and willingness to enroll in future web-based courses while controlling for 
student characteristics. (Unpublished doctoral dissertation). USA: University of Kansas. Retrieved from http://www.bookpump.com/dps/pdf-b/1121814b.pdf

Todd, W. (1992). Explaining our dreams: The artist's role in the evaluation of educational arts programs. Retrieved from https://eric.ed.gov/?id=ED377128, 2016.

Tsai, C. C., Chuang, S.C., Liang, J. C., \& Tsai, M. J. (2011). Self-efficacy in Internet-based learning environments: A literature review. Educational Technology \& Society, 14(4), 222-240. Retrieved from https://www.jstor.org/stable/10.2307/jeductechsoci.14.4.222

U.S. Department of Education, Office of Planning, Evaluation and Policy Development. (2009). Evaluation of evidence-based practices in online learning: A meta-analysis and review of online learning studies. Retrieved from www.ed.gov/about/offices/list/opepd?ppss?reports.html

Ustunel, H. H. (2016). The influence of critical factors on e-learning satisfaction. Baskent University Journal of Education, 3(2), 99-123. Retrieved from http://buje.baskent.edu.tr/index.php/buje/article/view/62

Yukselturk, E., \& Yildirim, Z. (2008). Investigation of interaction, online support, course structure and flexibility as the contributing factors to students' satisfaction in an online certi cate program. Educational Technology \& Society, 11(4), 51-65.

Wang, Y.-S. (2003). Assessment of learner satisfaction with asynchronous electronic learning systems. Information \& Management, 41(1), 75-86. doi:10.1016/S0378-7206(03)000284

Webster, J., \& Hackley, P. (1997). Teaching effectiveness in technology-mediated distance learning. Academy of Management Journal, 40(6), 1282-1309.

Wickersham, L. E., \& McGee, P. (2008). Perceptions of satisfaction and deeper learning in an online course. Quarterly Review of Distance Education, 9, 73-83.

Womble, J. (2008). E-learning: The relationship among learner satisfaction, self-efficacy, and usefulness. The Business Review, 10(1), 182-188.

Wood, B. B. (2001). Stake's countenance model: Evaluating an environmental education professional development course. The Journal of Environmental Education, 32(2), 1827.

Wu, J.-H., Tennyson, R. D., \& Hsia, T.-L. (2010). A study of student satisfaction in a blended elearning system environment. Computers \& Education, 55(1), 155-164. https://doi.org/10.1016/j.compedu.2009.12.012

Xu, D., Huang, W. W., Wang, H., \& Heales, J. (2014). Enhancing e-learning effectiveness using an intelligent agent-supported personalized virtual learning environment: An empirical investigation. Information \& Management, 51, 430-440.

https://doi.org/10.1016/j.im.2014.02.009

Appendix A. Factor Loadings and Reliability of Technological Anxiety and Satisfaction Scale

\begin{tabular}{|c|c|c|c|}
\hline $\begin{array}{l}\text { Independent } \\
\text { variables }\end{array}$ & Items & $\begin{array}{l}\text { Factor } \\
\text { loadings }\end{array}$ & $\begin{array}{l}\text { Cronbach's } \\
\text { Alpha of } \\
\text { the factors }\end{array}$ \\
\hline \multirow[t]{3}{*}{$\begin{array}{l}\text { Computer } \\
\text { anxiety }\end{array}$} & $\begin{array}{l}\text { 1. I am insecure about my computer skills. } \\
\text { [Bilgisayar becerilerim konusunda kendime guvenmem] }\end{array}$ & .79 & \multirow[b]{3}{*}{.85} \\
\hline & $\begin{array}{l}\text { 2. I am anxious when I work on computers. } \\
\text { [Bilgisayarla calısırken kaygilanirim.] }\end{array}$ & .89 & \\
\hline & $\begin{array}{l}\text { 3. I am quite relaxed when I work with computers. } \\
\text { [recode] } \\
\text { [Bilgisayrlarla calısrıken oldukca rahatim] }\end{array}$ & .68 & \\
\hline
\end{tabular}




\begin{tabular}{|c|c|c|c|}
\hline & $\begin{array}{l}\text { 4. I am apprehensive about working on computers. } \\
\text { [Bilgisayarlar uzerinde calısmam gerektiginde huzursuz } \\
\text { olurum.] }\end{array}$ & .73 & \\
\hline & $\begin{array}{l}\text { 5. I avoid working on computers. } \\
\text { [Bilgisayarlarla calısmaktan kacinirim.] }\end{array}$ & .71 & \\
\hline & $\begin{array}{l}\text { 6. I am less intimated by computers than most other } \\
\text { people I know. [recode] } \\
\text { [Bilgisayrlardan tanidigım bircok insandan daha az } \\
\text { korkarım.] }\end{array}$ & .72 & \\
\hline \multirow[t]{6}{*}{$\begin{array}{l}\text { Internet } \\
\text { anxiety }\end{array}$} & $\begin{array}{l}\text { 7. I feel confident about navigating the Internet.[recode] } \\
\text { [Internette gezinme konusunda kendime guvenirim.] }\end{array}$ & .67 & \multirow{6}{*}{\begin{tabular}{|l|l}
.77 \\
\end{tabular}} \\
\hline & $\begin{array}{l}\text { 8. I get anxious when I am required to use Internet } \\
\text { resources. } \\
\text { [Internet kaynaklarini kullanmam gerektiginde } \\
\text { kaygilanirim.][s: }\end{array}$ & .57 & \\
\hline & $\begin{array}{l}\text { 9. I get nervous about getting lost in cyberspace. } \\
\text { [Siber uzayda kaybolmaktan korkarım.] }\end{array}$ & .63 & \\
\hline & $\begin{array}{l}\text { 10. I get excited about using the internet. [recode] } \\
\text { [Interneti kullanmak beni heyecanlandirir.] }\end{array}$ & .69 & \\
\hline & $\begin{array}{l}\text { 11. I enjoy browsing the Internet. [recode] } \\
\text { [Internette gezinmekten keyif alirim.] }\end{array}$ & .68 & \\
\hline & $\begin{array}{l}\text { 12. I get confused when working with the internet. } \\
\text { [Internetle calisirken kafam karisir.] }\end{array}$ & .60 & \\
\hline \multirow[t]{6}{*}{$\begin{array}{l}\text { Online } \\
\text { course } \\
\text { anxiety }\end{array}$} & $\begin{array}{l}\text { 13. I am confident about working in the online } \\
\text { environment. [recode] } \\
\text { [Cevrimici ortamda calısma konusunda kendime } \\
\text { guvenirim.] }\end{array}$ & .74 & \multirow{6}{*}{.82} \\
\hline & $\begin{array}{l}\text { 14. I get anxious when I think about logging into my } \\
\text { online course. } \\
\text { [Cevrimici dersime giris yapmayi dusundugumde } \\
\text { huzursuz olurum.] }\end{array}$ & .77 & \\
\hline & $\begin{array}{l}\text { 15. I get nervous when I am required to participate in } \\
\text { online courses. } \\
\text { [Cevrimici derslere katilmam gerektiginde gerilirim.] }\end{array}$ & .88 & \\
\hline & $\begin{array}{l}\text { 16. I am apprehensive about enrolling in online courses. } \\
\text { [Cevrimici derslere kaydolma konusunda endiselenirim.] }\end{array}$ & .82 & \\
\hline & $\begin{array}{l}\text { 17. I am scared that someone will misinterpret my text- } \\
\text { based messages in the online environment. } \\
\text { [Cevrimici ortamda birisinin metin tabanli mesajlarimi } \\
\text { yanlis yorumlamasindan korkarim.] }\end{array}$ & .73 & \\
\hline & $\begin{array}{l}\text { 18. I feel empowered in my online courses. [recode] } \\
\text { [Cevrimici derslerimde kendimi yetkin hissederim.] }\end{array}$ & .71 & \\
\hline \multirow[t]{4}{*}{$\begin{array}{l}\text { Online } \\
\text { Learning } \\
\text { satisfaction }\end{array}$} & $\begin{array}{l}19.1 \text { am satisfied with the whole system of online } \\
\text { learning. } \\
\text { [Tum cevrimci ogrenme sisteminden memnunum.] }\end{array}$ & .66 & \multirow{4}{*}{.89} \\
\hline & $\begin{array}{l}\text { 20. Overall, online learning has been successful. } \\
\text { [Genel olarak, cevrimici ogrenme basarili olmustur.] }\end{array}$ & .91 & \\
\hline & $\begin{array}{l}\text { 21. I want to keep learning through the online learning } \\
\text { system in the future. } \\
\text { [Gelecekte de cevrimici ogrenme sistemiyle ogrenmeye } \\
\text { devam etmek isterim.] }\end{array}$ & .83 & \\
\hline & $\begin{array}{l}\text { 22. If I had an opportunity to take all courses via the } \\
\text { Internet, I would gladly do so. } \\
\text { [Butun dersleri internet uzerinden alma sansim olsa, } \\
\text { severek alirdim.] }\end{array}$ & .91 & \\
\hline
\end{tabular}




\section{Biographical notes:}

Dr. Suat Kaya is an Assistant Professor at Agri Ibrahim Cecen University, Turkey. He got his PhD from Department of Curriculum and Instruction at Middle East Technical University in Turkey. His current research interests include instructional technology, distance education, curricular studies, teacher education, teacher professional development and English language teaching. Orcid: 0000-0001-6593-3205 